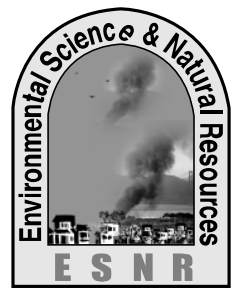

J. Environ. Sci. \& Natural Resources, 6(2): 49-53, 2013

ISSN 1999-7361

\title{
Impact of Fish Population Density on Growth and Production of Sarpunti, Mrigal and Tilapia in Polyculture System
}

\author{
S. N. Chowdhury, M. Paul ${ }^{1}$, A. C. Barman', A. Bhadra ${ }^{2}$ and M. S. Rahman \\ Department of Fisheries Management, BAU, Mymensingh \\ ${ }^{1}$ BFRI, Freshwater station, Mymensingh; ${ }^{2}$ BFRI, Headquaters, Mymensingh
}

\begin{abstract}
An experiment was conducted to determine the impacts of fish population density on the growth and production of sarpunti (Barbonemus gonionotus), mrigal (Cirrhinus mrigala) and tilapia (Oreochromis niloticus) in polyculture system for a period of 90 days in six earthen pond . The experiment was carried out under three treatments each with two replications. The stocking density was 50 fish per decimal (sarpunti 20, mrigal 20 and tilapia 10) under treatment-I, 75 fish per decimal (sarpunti 30, mrigal 30 and tilapia 15) under treatment-II and 150 fish per decimal (sarpunti 60, mrigal 60 and tilapia 30) under treatmentIII and all the ponds under three treatments supplementary feed was not used. The average initial length and weight of the fingerlings of sarpunti, mrigal and tilapia were $13.29 \mathrm{~cm}, 12.80 \mathrm{~cm}, 4.55 \mathrm{~cm}$ and $22.7 \mathrm{~g}, 23.75 \mathrm{~g}$ and $3.84 \mathrm{~g}$ respectively. The ponds were fertilized fortnightly with cowdung, urea and TSP at the rates of $5 \mathrm{~kg}, 100 \mathrm{~g}$ and $200 \mathrm{~g}$ per decimal, respectively. Mean survival rates of fish under treatment-I, treatment-II and treatment-III were $87.50 \%, 88.16 \%$ and $81.30 \%$ respectively. The specific growth rates (SGR, \% per day) of fish under treatment-I, treatment-II and treatment-III were $1.13 \%, 1.03 \%$ and $0.80 \%$. The calculated net fish production of the ponds under treatment-I was 1.61 ton/ha/yr and that of the ponds under treatment-II was $1.97 \mathrm{ton} / \mathrm{ha} / \mathrm{yr}$ and $2.5 \mathrm{ton} / \mathrm{ha} / \mathrm{yr}$ in treatment-III.
\end{abstract}

Key words: Mrigal, Tilapia, Sarpunti, Fingerlings, Cowdung.

\section{Introduction}

The association of fish species of different food habits in one pond is a polyculture system. It is based on the concept that each species participating in the polyculture has its own food niche and therefore does not compete for natural food with the other species (Tang, 1970) and thus increases fish yield per unit area. Since in modern aquaculture the tendency to increase density so as to utilize food resources to a maximum and increase yields per unit area, these interactions become more pronounced. High-density unbalanced polyculture or monoculture which has been called 'Ichthyoeutrofication' by Opusynski (1979) and has caused some concern with water supply biologists. In Bangladesh, different types of crop fishes are cultivated together for yielding high production and profit. Fish is the major protein source contributing about $60 \%$ of total animal protein intake. At present, fish consumption is only $13.5 \mathrm{~kg}$ per capita per year, whereas the requirement is about 18.0 $\mathrm{kg}$ (DoF, 2009). There are many causes for very low production of fish of which two are the most important. Firstly, lack of proper utilization and management of water resources and secondly, lack of adequate knowledge and research related to fish culture. To increase the fish production, the improved techniques and management practices should be developed. Among different culture techniques, polyculture is the most important cultural technique which is mainly practiced in perennial ponds to get maximum production within a short period (3-4 months). The selection of species for polyculture is important. Sarpunti (Puntius sarana) mrigal (Cirrhinus cirrhosus) and tilapia (T. mossambica) three high yielding species for aquaculture were selected for the present experiment because these species are suitable for low input culture system in small ponds and ditches and for their high growth. Bangladesh is a rural based developing country where more than $75 \%$ of the households in the rural Bangladesh spend more than $80 \%$ of their budget to fulfill the basic needs such as food, clothing and energy (BBS, 2004), therefore it is difficult to bear feed cost which in most cases cover $70-80 \%$ of the total expenditure of aquaculture. Therefore, to allow a real development of fish production among the poor people of the country, by applying only fertilizers give a sustainable production technique sought to reduce the burden on the household budget of the fish farmers. There are some important research works, on effects of fish population density on growth and production of fishes were done by Lakshmanan et al. (1968); Hepher et al. (1989); Lorenzen (2001); Saillant et al. (2003); Orpwood et al. (2004); Alim et al. (2005); Coman et al. (2007); in culture of different fishes and in overall cases of fisheries development. On the above aspect, this research work would be very helpful for determining the optimum population density by the fish farmers and also for further research in the future. So, therefore the present study was to determine the effects of fish population density on the growth and production of sarpunti, mrigal and tilapia under three treatments in polyculture; to determine the suitable population density of sarpunti, mrigal and tilapia for culture in ponds in polyculture system; and to determine the water quality parameters of the ponds under three treatments in polyculture system. 


\section{Materials and Methods}

\section{The ponds under the study}

The ponds were rectangular in size and similar in area (about $40 \mathrm{~m}^{2}$ ), depth and basin-bottom soil type and contour. The experiment was conducted in a series of six earthen ponds each having an average depth of $0.90 \mathrm{~m}$.

\section{Experimental design}

The experiment was conducted in Completely Randomized Design (CRD). There were three treatments each having two replications (Table 1).

Table 1. The layout of the experiment

\begin{tabular}{|c|c|c|c|c|c|}
\hline Treatments & Replication & $\begin{array}{c}\text { Pond } \\
\text { no. }\end{array}$ & $\begin{array}{c}\text { Ratio and combination of } \\
\text { species }\end{array}$ & $\begin{array}{c}\text { Fish population } \\
\text { density }\end{array}$ & Fertilization \\
\hline T-I & 2 & $\mathrm{P}_{2,} \mathrm{P}_{6}$ & $\begin{array}{l}\text { Sarpunti: Mrigal: } \\
\text { Tilapia=20:20:10 }\end{array}$ & 50 fish per decimal & \multirow{3}{*}{$\begin{array}{c}100 \mathrm{~g} \text { urea }+200 \mathrm{~g} \\
\text { TSP per decimal per } \\
2 \text { weeks }\end{array}$} \\
\hline T-II & 2 & $\mathrm{P}_{1}, \mathrm{P}_{4}$ & $\begin{array}{l}\text { Sarpunti: Mrigal: } \\
\text { Tilapia=30:30:15 }\end{array}$ & 75 fish per decimal & \\
\hline T-III & 2 & $\mathrm{P}_{3}, \mathrm{P}_{5}$ & $\begin{array}{l}\text { Sarpunti: Mrigal: } \\
\text { Tilapia }=60: 60: 30\end{array}$ & $\begin{array}{l}150 \text { fish per } \\
\text { decimal }\end{array}$ & \\
\hline
\end{tabular}

\section{Pond preparation}

Seven days after liming, urea and triple super phosphate (TSP) were applied at the rate of 100 $\mathrm{g} /$ decimal and $200 \mathrm{~g} /$ decimal respectively as and regular initial doses.

\section{Stocking of fish}

Fingerlings of Puntius sarana, Cirrhinus cirrhosus and Tilapia mossambica were stocked in the ponds of treatment-I at the density of 50 fish per decimal, 75 fishes per decimal in treatment-II and 150 fish per decimal in treatment-III after 7 days of fertilization. The initial average length of $P$. sarana, $C$. cirrhosus and T. mossambica were $13.29 \mathrm{~cm}, 12.80 \mathrm{~cm}$ and
$4.55 \mathrm{~cm}$ respectively. The initial average weight of $P$. sarana, C. cirrhosus and T. mossambica were $22.70 \mathrm{~g}$, $23.75 \mathrm{~g}$ and $3.84 \mathrm{~g}$ respectively.

\section{Study of water quality parameters}

Various water quality parameters water temperature $\left({ }^{0} \mathrm{C}\right)$, transparency $(\mathrm{cm})$, water depth $(\mathrm{m})$ were estimated and recorded fortnightly throughout the experimental period. Water quality measurements and sample collections were made between 9.00 a.m. and 12 noons. Chemical parameters such as $\mathrm{pH}$, dissolved oxygen $(\mathrm{mg} / \mathrm{L})$, free carbon dioxide $(\mathrm{mg} / \mathrm{L})$, total alkalinity $(\mathrm{mg} / \mathrm{L}), \quad \mathrm{PO}_{4}-\mathrm{P}(\mathrm{mg} / \mathrm{L}), \quad \mathrm{NO}_{3}-\mathrm{N}$ $(\mathrm{mg} / \mathrm{L})$.

\section{Estimation of survival rate, growth and production of fish}

(i) The survival rate was estimated by the following formula

$$
\text { Survival rate }(\%)=\frac{\text { No. of harvested fishes }}{\text { Initial no. of fishes }} \times 100
$$

(ii) Specific growth rate (SGR\%) was estimated by the following formula:

$$
\operatorname{SGR}(\% \text { per day })=\frac{\log _{\mathrm{e}} \mathrm{W}_{2}-\log _{\mathrm{e}} \mathrm{W}_{1}}{\mathrm{~T}_{2}-\mathrm{T}_{1}} \times 100 \text { (after Brown, 1957) }
$$

(iii) Calculation of gross fish production (ton/ha/yr)

$$
=\frac{\text { Gross weight }(\mathrm{kg}) \text { of fish perdecimal per month } \times 250 \times 12}{1000}
$$

(iv) Calculation of net fish production (ton/ha/yr)

$$
=\frac{\text { Net weight }(\mathrm{kg}) \text { of fish perdecimal permonth } \times 250 \times 12}{1000}
$$

\section{Statistical analysis}

T-test of net fish productions of the ponds under treatment-I, treatment-II and treatment-III was done by a computer using SPSS (Statistical Packages for Social Science, version 12) package programme.

\section{Results}

During the experimental period, a number of physico-chemical and biological parameters of water in all the experimental ponds were determined to find out suitability and fluctuations of the parameters. The results of' each of the water quality parameters of all the ponds have been given in Tables 2 . 
Table 2. Fortnightly fluctuation of physico-chemical factors of the ponds (*fish population density "A, B and C") under the experiment

\begin{tabular}{|l|c|c|c|}
\hline \multicolumn{1}{|c|}{ Factors } & $\begin{array}{c}\text { Treatment-I } \\
(\text { Mean } \pm \text { S.D) }\end{array}$ & $\begin{array}{c}\text { Treatment-II } \\
(\text { Mean } \pm \text { S.D) }\end{array}$ & $\begin{array}{c}\text { Treatment-III } \\
(\text { Mean } \pm \text { S.D })\end{array}$ \\
\hline Average water depth $(\mathrm{m})$ & $0.91 \pm 0.02$ & $0.92 \pm 0.01$ & $0.88 \pm 0.04$ \\
\hline Transparency $(\mathrm{cm})$ & $31.3 \pm 1.12$ & $30.80 \pm 2.01$ & $31.30 \pm 0.51$ \\
\hline Water temperature $\left({ }^{\circ} \mathrm{c}\right)$ & $31.55 \pm 0.84$ & $31.50 \pm 0.85$ & $31.50 \pm 0.85$ \\
\hline Air temperature $\left({ }^{\circ} \mathrm{c}\right)$ & $32.80 \pm 1.04$ & $32.80 \pm 1.04$ & $32.90 \pm 1.04$ \\
\hline Dissolved oxygen $(\mathrm{mg} / \mathrm{L})$ & $6.941 \pm 0.689$ & $7.208 \pm 0.327$ & $7.09 \pm 0.545$ \\
\hline Free $\mathrm{CO}_{2}(\mathrm{mg} / \mathrm{L})$ & $3.75 \pm 0.758$ & $4.50 \pm 0.632$ & $4.925 \pm 0.577$ \\
\hline $\mathrm{pH}$ & $7.39 \pm 0.182$ & $7.65 \pm 0.10$ & $7.48 \pm 0.125$ \\
\hline Total alkalinity $(\mathrm{mg} / \mathrm{L})_{\mathrm{PO}_{4}-\mathrm{P}(\mathrm{mg} / \mathrm{L})}$ & $175.5 \pm 25.19$ & $176.25 \pm 21.06$ & $170.5 \pm 12.57$ \\
\hline $\mathrm{NO}_{3}-\mathrm{N}(\mathrm{mg} / \mathrm{L})$ & $1.716 \pm 0.136$ & $1.883 \pm 0.075$ & $1.79 \pm 0.203$ \\
\hline
\end{tabular}

(* Fish population density A, B and C were 50, 75, 150 fishes per decimal)

\section{Survival rate, growth and production of fish}

The survival rate $(\%)$ of fishes was slightly different in different treatments. The survival rate in treatmentI was $87.50 \%$ and in treatment-II was $88.16 \%$ and in treatment-II was $81.30 \%$. The specific growth rates (SGR \% per day) of fishes in different treatments were different. The production of fishes was different in different treatments. The gross and net productions of fish of the ponds under treatmentI, treatment-II and treatment-III have been presented in the Table 3.

Table 3. Gross and net productions of fish of the ponds under treatment-I, Treatment-II and Treatment-III

\begin{tabular}{|c|c|c|c|c|}
\hline \multirow{2}{*}{ Treatment } & \multicolumn{4}{|c|}{ Production } \\
\cline { 2 - 5 } & \multicolumn{2}{|c|}{$(\mathbf{K g} / \mathbf{d e c i} / \mathbf{y r})$} & Gross & (Ton/ha/yr) \\
\cline { 2 - 5 } & Gross & Net & 2.51 & 1.61 \\
\hline T-I & 10.04 & 6.44 & 3.25 & 1.97 \\
\hline T-II & 13.00 & 7.88 & 4.84 & 2.50 \\
\hline T-III & 19.36 & 10.00 & \\
\hline
\end{tabular}

* Fish population densities in treatments I, II and III were 50 fish, 75 fish and 150 fish per decimal respectively.

Return from fish production per hectare per year

Return in terms of yield, gross return and net return were determined where gross return is the monetary value of yield and net return is the difference between gross return and total cost of production. In the present experiment the calculated gross return per hectare per year were Tk. 225900, Tk. 292500 and TK.435600 from the ponds of treatment-I, treatmentII and treatment-III respectively (Fig. 3).

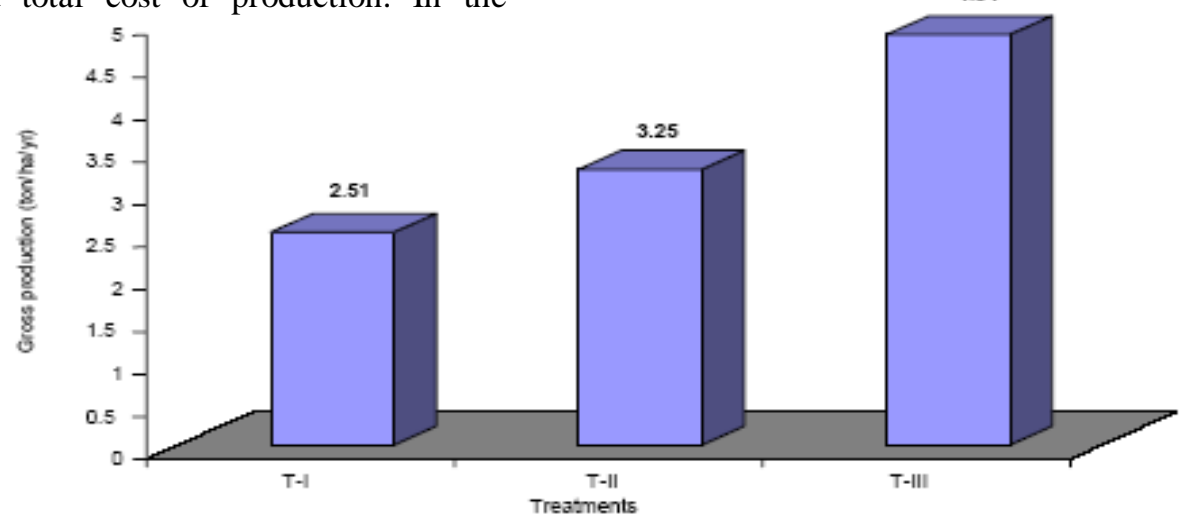

Fig. 1. Gross production of fish of the ponds under Treatment-I, Treatment-II and Treatment-III 


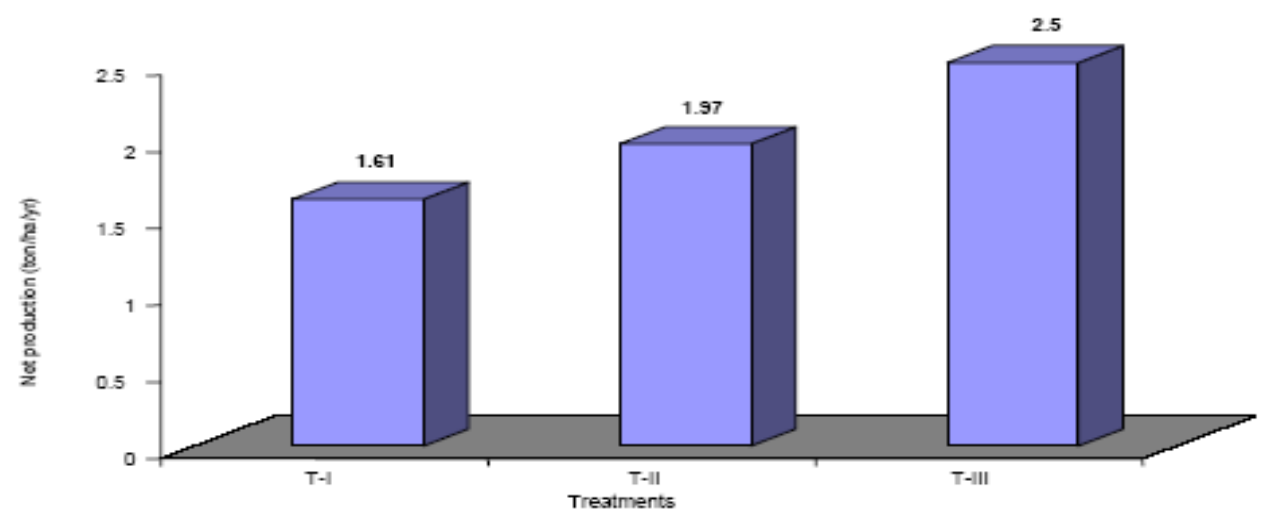

Fig. 2. Net Production of fish of the ponds under Treatment-I, Treatment-II and Treatment-III

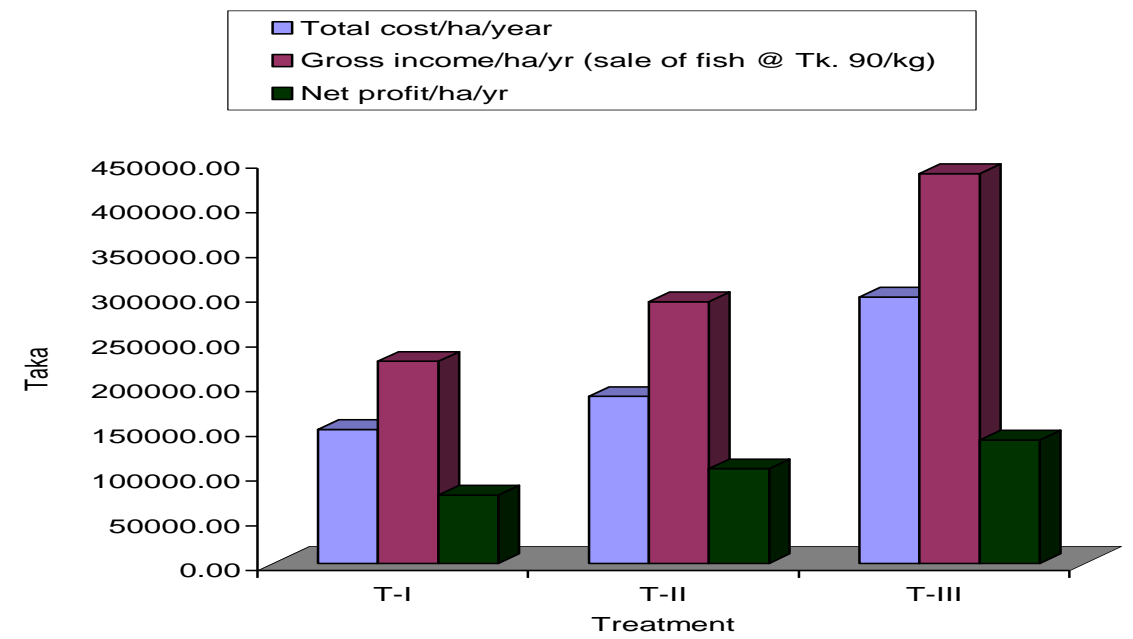

Fig. 3. Total cost, gross income and net profit per hectare per year in Taka under treatments I, II and III

\section{Discussion}

In the present experiment, the survival rates were different in different experimental ponds where the mean survival rates in treatment-I and treatment-II were higher $95.55 \%$ and $88.88 \%$, respectively which are statistically similar with the findings of Haque (2005) who recorded that the survival rates of $89.50 \%$ and $90 \%$ under treatment-I and treatment-II respectively in the monoculture of Thai sharpunti Puntius gonionotus. Kohinoor et al. (1993) obtained a survival rate of 86 to $94 \%$ in the monoculture of Thai sharpunti. The specific growth rates of rui, mrigal and silver carp (SGR\% per day) under treatment-I and treatment-II varied from 0.28 to $0.25 \%$ which was also similar to the finding of Hossain et al. (1997) who provided supplemental feed at the rate of $5 \%$ of total body weight daily whereas Khatun (2004) fed fresh duckweed at the rate of $40 \%$ of the total body weight. Net production of fish of treatment-I increased than that of treatment-II and it was $167.38 \%$ in comparison to treatment-II where net production was taken for $100 \%$. Kabir (2003) found 7.77 ton/ha/yr gross productions in duckweed-based polyculture system. Cost-benefit or percent benefit on investment under treatment-I and treatment-II were $51 \%$ and $26 \%$ respectively.

\section{Conclusion}

Finally, from the aforesaid discussion it is evident that in treatment-I, the growth rate of fish was high but the net fish production was comparatively lower than the other two treatments because of lower stocking density of fish population. In treatment-II, both the growth rate and the net fish production was moderate because of optimum stocking density of fish population. In treatment-III, the growth rate of fish was lower but the net fish production was higher than the other two treatments. Considering the cost-benefit analysis, the growth rate and production of fish was optimum in treatment-II. From this research work it 
may be concluded that 75 fish per decimal is the best stocking density for the culture of sarpunti, mrigal and tilapia in polyculture system.

\section{References}

Alim, M. A. 2005. Developing a polyculture technique for farmer's consumption and cash crop. Ph.D. Dissertation, Deptt. of Fisheries Management, Bangladesh Agricultural University, Mymensingh. p. 192.

BBS (Bangladesh Bureau of Statistics). 2004. Monthly Statistical Bulletin of Bangladesh. September 2004. Bangladesh Bur. Stat., Stat. Div., Ministry of Planning, Govt. of the People's Republic of Bangladesh.

Coman, G. J.; Arnold, S. J.; Jones, M. J. and Preston, N. P. 2007. Effect of rearing density on growth, survival and reproductive performance of domesticated Penaeus monodon. Aquaculture, 264(1/4): 175-183.

DoF. 2009. National Fish Week, 30 July to 5 August, 2009. Fish Culture in Flood affected Land. Deptt. of Fisheries, Ramna, Dhaka.

Haque, M.S. 2005. Use of duckweed (Lemna minor) as supplementary feed in monoculture of Sharpunti (Puntius gonionotus). MS thesis, Deptt. of Fisheries Management, Bangladesh Agricultural University, Mymensingh. 87 pp.

Hepher, B., Milstein, A., Leventer, H. and Teltsch, B. 1989. The effect of fish density and species combination on growth and utilization of natural food in ponds. Aquacult. Fish. Managt., 20: 59-71.

Hossain, M.A., M. Ahmed and M. N. Islam. 1997. Mixed culture of fishes in seasonal ponds through fertilization and feeding. Bangladesh J. Fish. Res., 1(2): 9-18.

Kabir, A. N. M. A. 2003. Use of duckweed (Lemna minor) as feed for fishes in polyculture. M.S. thesis, Deptt. of Fisheries Management, Bangladesh Agricultural University, Mymensingh.
Khatun, B. 2004. Effects of duckweed (Lemna minor) as supplementary feed on monoculture of tilapia (Oreochromis niloticus). M.S. thesis, Deptt. of Fisheries Management, Bangladesh Agricultural University, Mymensingh.

Khondker, M. and S. Rahim. 1993. Investigation on the water quality of Dhanmondi lake, Bangladesh. Periphytic and planktonic algae as indicators. Bangladesh J. Botany, 2(1):49-53.

Lakshmanan, M.A.V., Sen, P.R., Murty, D.S. and Chakraborty, D.P. 1968. Preliminary study on the rearing of carp finerlings. Indian $J$. Fish., 15(1\&2): 40-52.

Lorenzen, K. 2001. Using population models to assess culture-based fisheries: a brief review with an application to the analysis of stocking experiments. Reservior and culture based fisheries: biology and management. Proceedings of an International Workshop held in Bangkok, Thailand, from 15-18 February, 2000. pp. 257-265.

Opuszynski, K. 979. Silver carp, Hypophthalmichthys molitrix (Val.), in carp ponds. III. Influence on ecosystem. Ekologie Polski., 27: 117-133.

Orpwood, J.E., Griffiths, S.W. and Armstrong, J.D. 2004. Effect of density on competition between wild and hatchery reared Atlantic salmon for shelter in water. J. Fish Biol., 65(1): 201-209.

Saillant, E., Fostier, A., Haffray, P., Menu, B., Laureau, S., Thimonier, J. and Chatain, B. 2003. Effects of rearing density, size grading and parental factors on sex ratios of the Sea bass (Dicentrarchus labrax L.) in intensive aquaculture. Aquacult., 221(1/4): 183-206.

Tang Y. A. 1970. Evaluation of balance between fishes and available fish foods in multi species fish culture ponds in Taiwan in nursery ponds. Bangladesh J. Fish., 11(1): 83-88. 